This is a self-archived version of an original article. This version may differ from the original in pagination and typographic details.

Author(s): Kostiainen, Emma; Ukskoski, Tuija; Ruohotie-Lyhty, Maria; Kauppinen, Merja;

Title: Meaningful learning in teacher education

Year: 2018

Version: Accepted version (Final draft)

Copyright: 으 2017 Elsevier Ltd.

Rights: In Copyright

Rights url: http://rightsstatements.org/page/InC/1.0/?language=en

Please cite the original version:

Kostiainen, E., Ukskoski, T., Ruohotie-Lyhty, M., Kauppinen, M., Kainulainen, J., \& Mäkinen, T. (2018). Meaningful learning in teacher education. Teaching and Teacher Education, 71(April), 66-77. https://doi.org/10.1016/j.tate.2017.12.009 


\section{Meaningful learning in teacher education}

Emma Kostiainen ${ }^{1}$, Tuija Ukskoski ${ }^{1}$, Maria Ruohotie-Lyhty ${ }^{1,2}$, Merja Kauppinen ${ }^{1}$, Johanna Kainulainen $^{1,3} \&$ Tommi Mäkinen ${ }^{1}$

${ }^{1}$ Department of Teacher Education, University of Jyväskylä, Jyväskylä, Finland

${ }^{2}$ Department of Languages, University of Jyväskylä, Jyväskylä, Finland

${ }^{3}$ Department of Education, University of Jyväskylä, Jyväskylä, Finland 


\section{Meaningful learning in teacher education}

\section{Introduction}

Current understanding defines teaching as an emotional, relational, ethical and innovative profession (Beijaard, Meijer, \& Verloop, 2004; Kubanyiova \& Crookes, 2016; Munthe \& Rogne, 2015; Rodgers \& Raider-Roth, 2006; Keller, Frenzel, Goetz, Pekrun, \& Hensley, 2014). As a result, moral, emotional and relational dimensions as well as research orientation have also been highlighted in teachers' professional development (Kubanyiova \& Crookes, 2016; Munthe \& Rogne, 2015; Rodgers \& Raider-Roth, 2006). This is aligned with a greater shift away from previous cognition-centred ideas of learning towards an idea of learning embracing action and caring aspects (Dee Fink, 2013; Moate \& Ruohotie-Lyhty, 2014; Nilsson, Ejlertsson, Andersson, \& Blomqvist, 2015). However, while our understanding of teacher development has changed, this has not always been similarly reflected in teacher education practices (e.g. Parkes, 2013; Schelfhout et al., 2006).

Recent discussions of teacher education and teachers' professional development have regularly raised the problems of teacher education preparing teachers for delivering a predetermined curriculum instead of supporting their critical reflection and thinking skills (Edwards \& D’Arcy, 2004; Edwards \& Protheroe, 2003) and presenting teaching as a mere technical activity (Zeichner, 2014). As a result of these critiques, several changes to the pedagogy and curriculum of teacher education have been suggested in many recent studies (e.g. Girvan, Conneely, \& Tangney, 2016; Heikkinen, Tynjälä, \& Kiviniemi, 2011; Korthagen, 2004). Until now, there has, however, been little research on how these new approaches are working as part of teacher education and how they are experienced by the student teachers. More understanding is needed of how learners personally construe and construct their learning experiences (Billett, 2009, p. 33; Okukawa, 2008). Especially in teacher education programmes, the provision of meaningful learning experiences for students is considered critical for ensuring the student teachers understand what is to be learned (Daves \& Roberts, 2010). Understanding students' experiences of meaningful learning in teacher education is central to developing emotionally, relationally and morally sound pedagogical practices. This study offers a perspective into these issues by focusing on an obligatory course in a class teacher education programme in a Finnish university that has 
been experienced as deeply meaningful by student teachers during several consecutive years (Rasku-Puttonen, Klemola, \& Kostiainen, 2011; Tynjälä, Virtanen, Klemola, Kostiainen \& Rasku-Puttonen, 2016; Virtanen \& Tynjälä, 2013). This intensive course, focusing on the phenomena of interaction and cooperation in teaching, is situated in the context of curricular

and pedagogic development in a Finnish teacher education programme. The goal of the study is to understand what constitutes the experience of meaningfulness for students in the context of the specific course under study. The focus is on the realisation of the process characteristics of meaningful learning.

Of particular interest in our study are the examination of learning as a continuous meaningmaking process and identification of the characteristics of meaningful learning. Examining meaningful learning in the context of teacher education is important in order to gain a more refined understanding of the processes and experiences by which student teachers construct learning. This understanding could help teacher educators develop courses that foster experiences that enable richer and more relevant learning (Schmidt, 2010, p. 132). In such teacher education research it is important to position teacher students as learners and highlight their reflections on the meaningfulness of the learning (e.g. Loughran, 2002, p. 41). The aim is not to propose a one-fits-all model of course design, but to apply these findings to further develop worthwhile pedagogical practices in universities and teacher education.

\section{Theoretical framework}

\subsection{Learning as construction of meaning}

The aim of this qualitative study is to explore the features of meaningful learning experiences in the context of teacher education. Meaningful learning is understood as a concept describing personally valued, rich and worthwhile learning experiences (Billett, 2009; Hakkarainen, Saarelainen, \& Ruokamo, 2007; Merriam \& Clark, 1993; Okukawa, 2008) from the perspective of the learner, here student teachers.

Meaningful learning is usually described in terms of cognitive development and changes in the learner's cognitive structure (Ausubel \& Fitzgerald, 1961; Novak, 2002). In meaningful learning the knowledge learned must be relevant to existing knowledge and feature 
significant concepts and issues (Novak, 2002). This anchoring and situating of new knowledge and experiences into relevant prior knowledge and cognitive structure is important in facilitating meaningful learning (Ausubel \& Fitzgerald, 1961; Novak, 2002). Furthermore, the construction of meaning involves the interpretation of new information and experiences by connecting them with prior knowledge (Okukawa, 2008; Wolfe, 2006). This means that the perspective of those who interpret, the teacher students in our study, considerably affects the meaning-making process (Okukawa, 2008, p. 47). For instance, it is noted that meaningful learning is about to occur when the new knowledge does not fit the previous structures of knowledge (e.g. Jarvis, 1987). Experiences that challenge former knowledge allow new questions to arise and are thus potentially meaningful (Merriam \& Clark, 1993).

This approach to learning experiences advocates socio-constructivist and sociocultural learning theories, which emphasise that meaning making is a key element in constructivist thinking and in how learners construct meaning from experiences (Brookfield, 1986; Packer \& Goicoechea, 2000; Uhrmacher, 2002; Wolfe, 2006; Zepke \& Leach, 2002). Individuals differ in how they construe meanings (Berger \& Luckman, 1967). Thus, meaning making is the goal of learning processes, and learning environments that are participative and interactive provide students with opportunities to engage in meaning-making processes (Jonassen, Davidson, Collins, Campbell, \& Haag, 1995). In these interactive negotiating and reflecting processes individuals engage in meaning making and knowledge construction processes (Pena-Shaff \& Nicholls, 2004). This interactive nature of meaning construction and learning makes it more valuable, interesting and even revolutionary for the learner when it may make "a difference in how people live and the kind of life they are capable of living" (Dee Fink, 2013, p. 7).

\subsection{Characteristics of personally meaningful learning experiences}

The concept of personally meaningful learning experience refers here to students' learning processes and various events, activities and circumstances that they consider to have a special meaning to them (Hakkarainen et al., 2007, p. 89; Okukawa, 2008, p. 47). In our study, we are interested identifying what kinds of learning experiences provide teacher students with special value and how they construct this meaningfulness. To date, there have been only a few studies focussing on students' personal experiences of meaningfulness in the context of 
teacher education (e.g. Harvord \& MacRuairc, 2008; Korthagen, 2001a; Schmidt, 2010; Valli, Valli, \& Lähdesmäki 2017). However, meaningful learning experiences have been studied widely in the context of adult learning and non-formal education (e.g. Okukawa, 2008; Wolfe, 2006), medical and nursing education (e.g. Sousa, Formiga, Oliveira, Costa, \& Soares, 2015), and school learning in the classroom and in outdoor settings (e.g. Sharan, 2015; Taniguchi, Freeman, \& LeGrand Richards, 2005). In addition, research on meaningful learning in various online and virtual learning environments is substantial (e.g. Keskitalo, Pyykkö, \& Ruokamo, 2011; Tsai, Shen, \& Chiang, 2013). However, deeper understanding is needed of teacher education students' perceptions of meaningful learning. Teacher students may construct their identity as teachers based on their processes of meaning making (e.g. Bruner, 1990; Okukawa, 2008, pp. 49-50). Thus, the quality of their learning is an integral factor in their development as teachers and their teacher identity, as individual learning is inherently linked with changes in social role and identity (Bredo, 1994, p. 32).

Personally meaningful learning involves a diverse range of process characteristics. Prior research has shown that meaningful learning is likely to occur when learners are involved in constructive, active, intentional, relational and authentic processes (e.g. Brookfield, 1986; Fiddler \& Marienau, 2008; Hakkarainen et al., 2007; Jonassen \& Strobel, 2006; Keskitalo et al., 2011; Okukawa, 2008; Taniguchi et al., 2005) as further examined below.

\subsubsection{Constructive}

Meaningful learning involves continuous construction of the interpretations of actions and phenomena as well as the results of these actions (Jonassen \& Strobel 2006, p. 2). It is claimed that the learning experience becomes meaningful only when the learner him- or herself gives meaning to it: experiences must personally affect and be subjectively valued by the learner (Merriam \& Clark, 1993). All experiences are potential means of learning, but no experience solely guarantees more high-quality learning or behaviour (Watkins \& Marsick, 1992). Moreover, no learning experience or amount of experiences is as important as how an individual applies these gained experiences (Duran \& Kelly, 1994). This reflective orientation and critical consciousness through dialogue can help learning experiences to be more meaningful (Okukawa, 2008). The constructive dimension of meaningful learning enables reconstruction of the learner's self-image and sense of self and allows growth (Taniguchi et al., 2005). This can also manifest, for example, as an improvement in skills or the expediting of some desired change (Merriam \& Clark, 1993). 
Although meaningful learning is highly desired, it can also be quite an inconvenient and troubling experience and elicit awkward feelings, strong emotions and cognitive dissonance (Allard \& Gallant, 2012; Dirkx, 2001; Sterling, 2003; Taniguchi et al., 2005). According to Sterling (2003, pp. 287-288), this deep level of knowing or epistemic/transformative learning "can be deeply uncomfortable, because it involves a restructuring of basic assumptions caused by the recognition of "incoherence" between assumptions and experience". Uncomfortable feelings related to meaningful learning can be caused by experiences that challenge the learner's content mastery or by the unfamiliarity of the situation (e.g. Merriam \& Clark, 1993; Dee Fink, 2013; Taniguchi et al., 2005). A sense of risk-taking and feelings of awkwardness also seem to be related to meaningful learning experiences (Taniguchi et al., 2005, p. 135).

\subsubsection{Active and intentional}

Meaningful learning requires active individual agency and conscious goal setting. Thus, processes that are self-directed, goal oriented, purposeful and immersive are essential (Hakkarainen et al., 2007; Keskitalo et al., 2011). In meaningful learning "the learner chooses conscientiously to integrate new knowledge to knowledge that the learner already possesses" (Novak, 2002, p. 549). Consequently, programmes that are based on learners' characteristics and promote learners' high engagement and agency are likely to provide surroundings for meaningful learning (e.g. Brookfield, 1986; Zepke \& Leach, 2010). In order to engage in and aim for high-quality learning, students have to invest in their learning on many levels: they have to engage in making a cognitive contribution including active participation and reflection as well as emotional commitment (ACER, 2008; Korthagen 2001b). According to Sterling (2003), when students experience a sense of ownership and deep engagement toward learning and when that learning resonates with one's core values, it can be interpreted as being 'transformative', the highest level of learning. One characteristic of meaningful learning is that it not only supports and anchors existing knowledge but also goes beyond content mastery (Dee Fink, 2013).

\subsubsection{Relational}

The relational dimension of the learning process - need for interaction, collaboration and enthusiasm in and between teaching staff, students and the teaching process - is evident in providing meaningful learning experiences (Bryson \& Hand, 2007; Okukawa, 2008). Student 
engagement is shaped by teacher-student interaction and the role of the teacher. Teachers who are present, approachable and have a passionate orientation toward their work and are able to create deep learning experiences promote student engagement (e.g. Hooks, 1994; Kuh, Kinzie, Buckley, Bridges, \& Hayek, 2006). Learners' reflective processes that are supported by close human relations with teachers and others give great significance to their learning experience (Okukawa, 2008, p. 53). Placing high investment into learning and evolving into close collaborative relationships as well as the reflective process of meaningmaking is emotionally involving, which is one characteristic of meaningful learning (e.g. Dirkx, 2001; Hakkarainen et al., 2007). In that regard, emotional intelligence (Goleman, 1995) as well as aspects of the human dimension and caring (Dee Fink, 2013) are also important.

\subsubsection{Authentic}

A characteristic of authentic learning experiences is that they are personally relevant to the learner and situated within a proper social context (Stein, Isaacs, \& Andrews, 2004). Hence, meaningful learning requires meaningful tasks that emerge from an authentic, or at least simulated, context or experience. When a learner ponders authentic problems the problems are better understood and derived understanding is more likely to be transferable to new situations because the problems have real contextual meaning (Jonassen \& Strobel, 2006, p. 2). Because of the contextual dimension of meaningful learning and the different ways that individuals construe meanings (Berger \& Luckman, 1967), the personal significance of a certain experience may vary from individual to individual (Merriam \& Clark, 1993).

In summary, personally meaningful learning can consist of various process characteristics and be enhanced in many ways. Additionally, meaningful learning is also a more ontological orientation to learning. From this ontological perspective, $\mathrm{Su}$ (2011) uses the concept of a 'being' mode of learning, arguing that 'being' (Heidegger, 1978) includes the thought, action and affect of the learner and "provides a more person-focused approach that is useful for providing balance and congruence between feeling and thought and between mind and body, supplementing the having and doing approaches---" (Su, 2011, p. 400). Therefore, it is particularly important to gain understanding of how to facilitate rich and valuable learning experiences in the context of teacher education. 



\section{The study}

\subsection{Research questions}

Rather than describing learning outcomes, we sought to better understand what features of learning are experienced to be meaningful and why. We therefore used a qualitative approach (Braun \& Clarke, 2006; Marton, 1994; Miles \& Huberman, 1994) to examine the qualitatively different ways to perceive personally meaningful learning experiences related to an intensive course promoting social competence and interaction skills held at the University of Jyväskylä, Finland. As teacher educators, we have seen a broad spectrum of learning experiences including some that are meaningful to some students and almost meaningless to others (see also Taniguchi et al., 2005, p. 131). However, according to student feedback and the findings of previous studies regarding the course under study, Interaction Skills in a Group and Network (ISGN), the teacher-students have repeatedly evaluated the course contents and methods exceptionally positively (Rasku-Puttonen, Klemola, \& Kostiainen 2011; Virtanen \& Tynjälä, 2013). Additionally, at the university level the course ranks among the top three course modules that have proven to be efficient in learning generic skills and which have been highly rated by university students in terms of teaching the knowledge and skills needed in working life (Virtanen \& Tynjälä 2013, p. 4; Tynjälä et al., 2016). Therefore, the aim of this study was to explore the ISGN course further in order to outline the basic features of personally meaningful learning in teacher education based on the experience of the teacher students. The focus of study was not the learning outcomes of the students, but what they consider meaningful in their learning experience. To examine their learning experiences, we asked the following research questions:

RQ1: What makes learning meaningful for teacher students?

RQ2: What features of teaching and learning in teacher education produce meaningful learning?

\subsection{Participants and procedures}

The study participants comprised 71 male $(n=18)$ and female $(n=53)$ undergraduate students, primarily second-year teacher students, who all took part in the ISGN course. The age range 
of the participants was $20-53$ years and the majority (90\%) were under 30 years old. The participants represented a range of socioeconomic backgrounds, reflecting Finnish teacher education in general in which student teachers are selected from across the whole spectrum of society.

The data consisted of 71 student essays (131 pages in total). After the intensive course, the participants were asked to write a reflective essay with the following instruction: 'Choose any essential or significant phenomenon or occurrence in your group that you experienced to be meaningful during the intensive course and reflect on it drawing on appropriate literature'. Because individuals differ in how they construe meanings (Berger \& Luckman 1967), the students were allowed to freely choose any occasion, situation or feature of the ISGN course that they personally considered meaningful. The participants were not steered in their choice of topic, as it was important that the students themselves chose the theme or situation and defined what they learned and why. The essays were thereby intended to be more authentic and thus offer a fuller spectrum of the participants' learning experiences. The participants were informed that their essays would, by their consent, be used for research purposes and no one refused to take part in the research.

\subsection{Context: intensive course module}

The curriculum of the Department of Teacher Education at the University of Jyväskylä emphasises the importance of interpersonal skills and social interaction as one of the six key competences of the teacher education programme. The six competences are: 1) ethical;2) intellectual; 3) communication and social interaction; 4) cultural, communal and societal; 5) pedagogical; and 6) aesthetic competence (University of Jyväskylä Teacher Education Curriculum 2014-2017). Within the curriculum, the intensive course module Interaction Skills in a Group and Network (ISGN) focuses on developing teacher students' social interaction competence and was the data gathering context of this study. Communication and social interaction competence means that the student is willing and able to collaborate with others in various interpersonal events, groups and relationships. The theoretical framework, aims, pedagogical principles and teaching and studying methods of the ISGN course are presented in Table 1 (a detailed description of this implementation can be found in RaskuPuttonen, Klemola, \& Kostiainen, 2011; Tynjälä et al., 2016). 
Table 1. Description of the Interaction Skills in a Group and in Networks course (Tynjälä et al., 2016, p. 372).

\begin{tabular}{|c|c|}
\hline $\begin{array}{l}\text { Course module } \\
\text { descriptions }\end{array}$ & Interaction Skills in a Group and in Networks \\
\hline Credits & 4 \\
\hline $\begin{array}{l}\text { Theoretical } \\
\text { framework }\end{array}$ & $\begin{array}{l}\text { Sociocultural theories } \\
\text { Socioconstructivism } \\
\text { Dynamic group processes }\end{array}$ \\
\hline Aims & $\begin{array}{l}\text { Student } \\
\text { - } \quad \text { is able to analyse his/her social competence } \\
\text { - } \\
\text { is able to recognise and evaluate group processes and his/her } \\
\text { - } \\
\text { - } \\
\text { recognividualistic behaviour as a member of a group } \\
\text { has the capability to improve the welfare of the learning } \\
\text { community }\end{array}$ \\
\hline Students & Primary school teacher students in their second academic year \\
\hline Teachers & Team of teacher educators from different disciplines \\
\hline $\begin{array}{l}\text { Pedagogical } \\
\text { principles }\end{array}$ & $\begin{array}{l}\text { One week. } \\
30 \text { hours contact teaching, ca. } 80 \text { hours independent work. } \\
\text { Integrative pedagogy. } \\
\text { Belonging to the group. } \\
\text { Active participation. } \\
\text { Reflecting on experiences. } \\
\text { Focus on the phenomenon of social interaction. } \\
\text { Learning processes support learning content. } \\
\text { Special emphasis on beginning and ending the course module. } \\
\text { Holistic view of the learner. } \\
\text { Increasing awareness of own emotions, behaviour and reactions. } \\
\text { Multiprofessional cooperation. }\end{array}$ \\
\hline $\begin{array}{l}\text { Teaching and } \\
\text { study methods }\end{array}$ & $\begin{array}{l}\text { Whole group sessions. } \\
\text { Small group activities. } \\
\text { Open discussions. } \\
\text { Simulations. } \\
\text { Role play. } \\
\text { Teacher as a member of the group. } \\
\text { Peer reflection. } \\
\text { Perceiving, naming and regulating emotions. } \\
\text { Commitment to and trust in the group. } \\
\text { Reflective reading and writing. } \\
\text { Versatile methods for receiving and providing feedback and } \\
\text { evaluations about the course and the activities in the group. }\end{array}$ \\
\hline Assessment & $\begin{array}{l}\text { Rating scale } 0-5 \\
\text { Includes an essay and student self-assessment of the intensive course }\end{array}$ \\
\hline
\end{tabular}

During an intensive week, the participants worked in whole group sessions (activating lectures) and in six small groups (approximately 16 students per group) with their teachers. 
The six teachers planned and implemented the course together and worked as a team throughout the week, although each had their own group under their guidance. The aim was to promote social competence and interaction skills: each day had a specific theme (e.g. group dynamics, challenges in interpersonal relationships) and learning methods that supported the themes (Rasku-Puttonen et al., 2011; Tynjälä et al., 2016). The course was carried out within the framework of integrative pedagogy (e.g. Heikkinen et al., 2011; Tynjälä et al., 2016), which emphasises the sociocultural theories (e.g. Lave \& Wenger 1991) and the socio-constructivist approach to learning (e.g. Packer \& Goicoechea, 2000). This approach underlines how meaning-making is a key element in constructivist thinking, how learners construct meaning from experiences and how participation and learning in a community is essential (Brookfield, 1986; Packer \& Goicoechea, 2000; Uhrmacher, 2002;

Wolfe, 2006; Zepke, \& Leach, 2002).

\subsection{Data analysis}

The qualitative data was analysed using the thematic step-by-step analysis of Braun and Clarke (2006) and the process of systematic coding (Miles \& Huberman, 1994). The data analysis consisted of three interactive sub-processes: generating initial codes based on the qualitative content analysis, identifying themes, and naming the main categories. The phases of the analysis, with illustrative concrete examples, and their connection to research questions are presented in Table 2 .

Generating initial codes and data reduction means reducing, simplifying and transforming the raw data into a manageable form. In the present study, this was accomplished through identifying initial codes in the raw data. The codes served as organising principles for the qualitative data: the initial codes could be expanded and changed during the repeated interactions with the data and research team. The qualitatively different ways of experiencing the phenomenon (meaningful learning) were the units (sentence, paragraph, or phrase) of analysis (Marton, 1994). For example, statements such as 'My chosen topic is the good spirit, trustworthiness and cohesiveness of my group during the intensive and interactive week' and 'When we went on Friday to the last lecture of the course, we walked there as a group which has learned both from ourselves as individuals and from each other' were coded under the same category (the group). In this first phase of analysis triangulation was used: the research team cross-checked the codings to ensure the consistency of the coding logic and the coding 
discrepancies were negotiated and checked over carefully. Resultant codes were discussed between the authors for agreement and clarification. As a result of the first analysis phase, 11 categories were created to which the students' meaningful experiences were connected: 1) Activities/task, 2) Challenging situation, 3) The teacher, 4) The group, 5) Time/timing, 6) Theory, 7) Feedback, 8) Emotion, 9) Learning, 10) Applying, and 11) Self.

Table 2. Phases of the analysis

\begin{tabular}{|c|c|c|}
\hline $\begin{array}{l}\text { Phase } 1 \\
\text { Generating initial codes: issues } \\
\text { mentioned by participants as } \\
\text { meaningful. }\end{array}$ & $\begin{array}{l}\text { Phase } 2 \\
\text { Identifying themes. } \\
\text { Answering RQ1. }\end{array}$ & $\begin{array}{l}\text { Phase } 3 \\
\text { Naming main } \\
\text { categories. } \\
\text { Answering RQ2. }\end{array}$ \\
\hline $\begin{array}{l}\text { Task/activities } \\
\begin{array}{|l}\text { Example: } \\
\text { "I felt a very strong sense of } \\
\text { belonging to my group } \\
\text { during the bridge-building } \\
\text { [simulation] exercise. I felt I } \\
\text { was a useful member and not } \\
\text { an outsider. As far as I could } \\
\text { tell, no one was left outside } \\
\text { our group because everyone } \\
\text { played an important part in } \\
\text { our mission." }\end{array}\end{array}$ & $\begin{array}{l}\text { Importance of the phenomenon } \\
\text { and theme } \\
\text { Common goal and commitment } \\
\text { Intensiveness } \\
\text { Linking theory and practice }\end{array}$ & Course design \\
\hline Challenging situation & Daring and taking risks & \\
\hline $\begin{array}{l}\text { Example: } \\
\text { "When I was waiting for my } \\
\text { turn I was all tensed up and } \\
\text { nervous. My hands sweated } \\
\text { and my pulse raced. Loads of } \\
\text { questions ran through my } \\
\text { head: How will the others } \\
\text { react? Can I trust them? Am I } \\
\text { telling too much? Am I even } \\
\text { able to express my most inner } \\
\text { feelings in front of practically } \\
\text { strangers? I was able to open } \\
\text { up, because the situation and } \\
\text { the company were just right." }\end{array}$ & $\begin{array}{l}\text { Becoming heard and seen } \\
\text { Belonging, equality, and roles } \\
\text { Sense of subjectivity } \\
\text { Safety } \\
\text { Authenticity and trust } \\
\text { Feeling of bafflement and } \\
\text { wonder }\end{array}$ & $\begin{array}{l}\text { Gaining strong } \\
\text { experience }\end{array}$ \\
\hline $\begin{array}{l}\text { The teacher } \\
\text { The group } \\
\text { Time/timing }\end{array}$ & & \\
\hline
\end{tabular}




$$
\begin{array}{|l}
\text { Theory } \\
\text { Feedback } \\
\text { Emotion } \\
\text { Learning } \\
\text { Applying } \\
\text { Self }
\end{array}
$$

The second phase of analysis, identifying themes, involved systematic analysis of the data. Recurrent themes were first searched across the data within the categories found in the first phase. Answering RQ1 then revealed the reasons why and how a certain matter, situation, or occasion was experienced to be meaningful and stated as having a certain meaning. Qualitative analysis of the students' reflections identified 11 common themes of personally meaningful learning experience. For example, a statement in which a participant describes a particular meaningful task or activity (see Table 1, Phase 1) was interpreted as representing the themes common goal and commitment and becoming heard and seen. Finally, naming the main categories and answering RQ2 involved a process of identifying the central findings and drawing conclusions from the organised data. The themes that in the second phase represented the characteristics of meaningful learning could be construed under three main categories: course design, gaining strong experience and broad spectrum of emotions. These cross data findings are reported in more detail in the findings section.

\subsection{Findings}

The analysis revealed eleven dimensions that make learning experiences meaningful for teacher students (RQ1). These are: 1) Importance of the phenomenon and the theme; 2) Common goal and commitment; 3) Intensiveness; 4) Linking theory and practice; 5) Daring and taking risks; 6) Becoming heard and seen; 7) Belonging, equality, and roles; 8) Sense of subjectivity; 9) Safety; 10) Authenticity and trust; and 11) Feeling of bafflement and wonder. In addition, these 11 themes formed three main intertwined dimensions that are necessary to generate meaningful learning experience in the context of teacher education (RQ2): 1) Course design; 2) Gaining strong experience; and 3) Broad spectrum of emotions. The results are presented according to these three main categories and the 11 subcategories of these dimensions, which provide insights into the features of the dimensions. In the results, the letters and numbers in parentheses that follow example 
statements refer to data from which the quotations are drawn (e.g. F34: $\mathrm{F}=$ female/M=male, $34=$ the serial number of the essay $(n=71)$.

\subsection{Course design}

To achieve meaningful learning, a goal-oriented structure of the overall learning process seemed to be important. According to the analysis, the overall course design supported participants' learning with respect to both course structure and the course content. The key features characterising this dimension were: 1) Importance of the phenomenon and the theme; 2) Common goal and commitment; 3) Intensiveness; and 4) Linking theory and practice.

\subsubsection{Importance of the phenomenon and the theme}

Participants found the studied phenomenon, interaction skills, important and relevant. Strengths and weaknesses in interaction can essentially be traced directly to experiences of success or failure in the teacher's work. Interaction skills are therefore crucial for individuals' subjective growth and for the development of teacher identity.

Moreover, the interactive way of studying, where teaching and learning methods are planned to support the overall phenomenon, was motivating. The overall course design and the importance of the theme are mentioned in the following excerpts:

\footnotetext{
I have never experienced this kind of arranged environment that has a notably 'fertile base' for interaction. After the first day I was excited about the course and everything that it would contain going forward. (M23)

---I tried to adopt everything I learned into my own actions. ---I feel the future is a positive challenge, which I can approach more confidently after this course. (F51)
}

Not only was the course content with its exercises applicable and transferable to the participants' future work, but it was evident that the course generated a strong will to apply the knowledge learned in the future as a teacher.

---in the future as a teacher I shall be the guide and the head of my group and [strive to] enable experiences of participation in school. It is high time, therefore, to get to know this theme as closely as possible. (M01) 


\subsubsection{Common goal and commitment}

The participants showed a strong commitment to and interest in their group and group members, as well as the phenomenon under study. Shared goals foster a sense that everyone has something to offer, which is in itself rewarding. The goal was experienced as clear and shared among group members.

We were interested in each other's thoughts and experiences along with a common will to improve one's own interpersonal skills. (F34)

Participants' descriptions of meaningful experiences mirrored the idea that the unit of learning was the group rather than the separate individual. Understanding the relational aspect of the self-concept - how relationships with others shape our self-concept - is important for student teachers' professional development. Thus, learning was a negotiation process at the group level, which the entire group lived through together. Because of their jointly framed common goal, each member had a strong will to devote their efforts to the course. In particular, sharing emotions seemed to be meaningful in terms of commitment to the group: participants frequently expressed positive feelings towards other group members.

The more we got to know each other in our small group, the more we liked each other. ---The shared respect towards all members of the group, the teacher's constant encouragement and the assignment that had us listing positive features about each other were notable status-builders. I believe that our group possessed a strong sense of cohesion, which was exemplified by efficiency, enjoyability, motivation, a sense of caring, a sense of rewarding, a good vibe, the process of sharing feelings and overall a wealth of communication. (F13)

Near the end of the course, I noticed that I liked every member of our group, at least to a certain degree. Some of them I liked quite a lot. (M61)

The course assignments were planned to be challenging for the participants. The participants responded with a dedicated orientation toward the learning assignments. This was evident both in their choosing challenging assignments voluntarily, and in their motivation to invest in the assignments designed by the teachers.

Additionally, in that assignment I was in my discomfort zone which I want to narrow down and become conscious of. (M12) 
We were given the chance to decide how we would give feedback to each other. We chose the hardest route. $(\mathrm{F} 62)$

\subsubsection{Intensiveness}

The analysis revealed that the experience of intensiveness was a result of several factors during the course. The course design produced the following intensive elements: 1) a contact course length of one week; 2) getting to know each other in a short period of time; 3) in-depth examination of themes day by day; and 4) simultaneous reflection of theory and practice. These elements helped and forced participants to focus on important and relevant issues, which is essential to reach meaningful learning. Working together for a whole week accumulated several shared experiences that strengthened understanding among the participants.

---we had our own 'home' group within the basic course in education; another intensive group was also shaped there [within the basic course in education] during the year, but it did not lead to the same level of openness [as the 'ISGN group'] and it took a long time. I would say the most important reason for this was the buoyancy of the assignments given [to the 'ISGN group']. (M39)

The intensive week was by and large a success. The biggest factor in this success was the intensiveness of our group. It was fantastic to notice how open and intimate the overall atmosphere of our group became in just a week. (F14)

Furthermore, characteristic of meaningful learning, the learning process remained active even in the participants' own time, and, by the end of the week, they realised where the process had been leading them:

I spent the entire evening mentally processing my experiences, what the others had to say and the joint exercises we had done that day. (F15)

By the end of the week the conversations we had on Monday felt quite dull. (M20)

\subsubsection{Linking theory and practice}

According to the results, the course design provided an appropriate interplay between theory and practice. The methods used supported the phenomenon under study. In the participants' view, the simultaneous strong presence and reflection of the self through theory turned the theory into an element that explains the participant's own behaviour, reactions, and 
experienced emotions. For the participants, the theory was an immediate, not distant or abstract, tool in reflecting and understanding. Thus, the theory did not remain disconnected but became personal, which is prerequisite for meaningful learning. According to the participants, the urge to understand the theory arose together with a desire to theoretically explore their subjective experience.

We shared in the group some experiences that had been significant to us and, after hearing one story, I found myself bursting with thoughts and questions. The case really got me thinking, and I wanted to study and analyse it even more by getting to grips with the theory. (F43)

---experiencing and analysing the group process provided lots of useful guidance for teaching. ---By recognising the phases of group development and its social structure, the teacher can better understand their pupils and their behaviour and is able to create a positive environment for interaction and learning. (F35)

\subsection{Gaining strong experience}

Gaining strong experience seemed to be an important necessary aspect of meaningful learning. The key features characterising this dimension were: 1) daring and taking risks, 2) becoming heard and seen, 3) belonging, equality and roles, and 4) a sense of subjectivity.

\subsubsection{Daring and taking risks}

Daring and taking risks featured strongly in the participants' essays. Being urged to confront one's discomfort zone and discuss difficult topics creates learning experiences that are valuable for the future teacher. It is important to understand that self-disclosure and openness are not easy, but essential features of the future teachers' work with their pupils and colleagues. During the course, there was a high developmental leap within this dimension.

I wasn't excited about the intensive week. Life has really been kicking me in the head lately, so I've adopted an attitude of not assuming positive things about anything or anyone. ---So this was my 'ideology’ heading into the intensive week. ---However, the week ended up giving me so much more. I began to understand myself and my feelings much better and if I may inject a bit of hyperbole here, I could say this week changed me as a person. (F30)

Risk-taking was catching. When one participant showed daring, the others were more daring, too, as described in the following: 
In our first meeting, we sat in a circle and observed each other with great curiosity. ---Most members had not met anyone in the group previously. ---our first assignment began to roll forward according to the classic snowball principle. We had to draw a picture about the person sitting next to us ---and follow it up with a self-imagined story about that person. The first stories that were read aloud were very subtle in content. ---The further on we went in our circle, the wilder our stories became. (F31)

\subsubsection{Becoming heard and seen}

The individual's experience of becoming noticed was considered extremely important and necessary, even though talking about oneself was not easy. Receiving novel feedback that shed new light on oneself was also valued. The participants' individual experience of being accepted, valued and important to each other represents a caring aspect that is central to their future work as teachers.

All the group members' stories were listened to and focused on and you could pose clarifying questions or comment freely. It genuinely felt that everyone listened to everybody's story wholeheartedly. (F40)

---I received feedback that I have never had before, such as that I consciously take other people into account, even though I have often felt I'm not viewed that way at all. (M60)

\subsubsection{Belonging, equality and roles}

According to the participants, a strong sense of belonging and sharing developed during the intensive week. The will to spend time together and to develop interpersonal skills after the course module remained among some participants. This level of immersion in the themes under study demonstrates the meaningfulness of shared experiences to the participants.

I felt on Friday that I would have done almost anything to get our group to continue. Luckily some others also felt similar strong emotions towards the group and we set up a follow-up group under the cover of which we meet each other either over lunch at the university canteen, at each other's homes or in restaurants. (F40)

The equality of all participants in the course module - including the teachers - was seen as important. For preservice teachers it is important to observe the teachers' role from the perspective of an equal. The value of positioning the teacher as an equal member of the group was frequently mentioned in the participant essays. 
Starting from the first moment the [teacher] came down to our level. Instead being just a supervisor or a teacher she revealed her persona and told us openly about her life and thoughts. ---it was also necessary for the supervisor to serve as a model and to create the right group atmosphere. (F14)

It was also considered important that participants could take a role in the group, which was unusual for them. Furthermore, the participants found they could learn about different roles and encountered roles that departed from their preconceptions.

\footnotetext{
When we examined the process towards the end of the course, it turned out that many members had assumed a 'different' role on purpose, so that they could get a new viewpoint into that role in a group setting. It was interesting to hear what these different roles felt like to them. Some members even said that they were confused by their own actions. (F16)

I had assumed that one member was very talkative and a strong leader-type, but I ended up seeing his softer side when he told us about a sad experience. On the other hand, a member I had perceived as arrogant had done a very unselfish deed that had resulted in a lot of good for many others. (F15)
}

\subsubsection{Sense of subjectivity}

According to the results, it may be interpreted that the participants were unable to escape their 'being' and subjectivity as group members. They realised that whatever they did or did not do as individuals had an impact on the other participants in the group and thus felt a sense of subjectivity.

\footnotetext{
I felt I was a useful member and not an outsider. As far as I could tell, no one was left outside our group because everyone played an important part in our mission. (F19)
}

I learned an unbelievable amount about myself and group dynamics during the week. ---I found I am an adaptive member of the group. If need be, I can be a leader, a shoulder to cry on, a subtle participant in the background or even the joker of the group. The group itself defines who I am. Or more so, I define who I am based on the conclusions I make from being in the group. (F31)

\subsection{Broad spectrum of emotions}

According to the results, meaningful learning is closely linked with participants' emotions. In particular, the possibility to experience a broad spectrum of emotions seemed to enhance meaningful learning. This requires that the learning processes undertaken should not restrict 
the range or depth of possible emotions. The features characterising this dimension were: 1) safety, 2) authenticity and trust, and 3) feelings of bafflement and wonder.

\subsubsection{Safety}

The participants considered speaking about emotions and their meaning to be important in fostering a safe atmosphere and welding the group together. Creating a safe environment also enabled the participants to express a broad spectrum of emotions. This demonstrates the importance of creating a safe learning atmosphere for preservice teachers.

The link between emotions and safety are expressed in the following excerpts:

The phenomenon [the expression of emotions] concretely occurred in our small group meetings: when we shared emotional experiences our group welded even more tightly together. (F59)

I tend to usually just follow from the sidelines, but now I have dared to put forward my own experiences, my own opinions, and comment on others' issues as well as just listening. (F30)

\subsubsection{Authenticity and trust}

The participants wrote that the emotions they experienced and showed during the intensive course were real. Their authentic and individual experiences thus made their learning personally valued. Also, the importance of fellow participants and the teacher also sharing emotions was essential: authenticity and the desire to express real emotions seemed to spread from one group member to another.

The themes we dealt with spurred and encouraged open interaction and sharing your own experiences. This open sharing of personal feelings and listening to others' experiences clearly brought us closer together ---the whole group was really present and the mood varied according to the shared experiences. The atmosphere was open, approving and emphatic and the members of our group, one after another, were encouraged to share increasingly more sensitive and private feelings. ---Thus, many of us ended up sharing more personal and revealing experiences than we had initially planned. (F32)

Trust among the participants fostered the courage to share difficult emotions and fears, which is an important aspect of the students' well-being both during studenthood and later in their future work:

When choosing my topic to share, I dared to take the bull by the horns and confront my fears because I trusted my group members. (F36) 


\subsubsection{Feelings of bafflement and wonder}

The participants' essays also revealed feelings of bafflement and wonder. These awkward, challenging feelings seemed to play a part in meaningful learning. The intensive course caused an upwelling of emotion and shook their feelings. According to the participants' accounts, these experiences seem to have arisen from being brought outside their comfort zone: the course and the group spoke to them, and they had to stop to think and wonder.

I did start feeling a little anxious when several members of our group were talking about very delicate subjects, such as experiencing the death of a loved one. I didn't really know how to react in a situation like that. Should I say or do something comforting ---should I look away at something else, so as to not make the situation any more awkward for the speaker? In any case, I ended up staring at the floor as hard as I could. ---I even felt like I blushed at one point, although I wasn't sure why. (F15)

When I was waiting for my turn I was all tensed up and nervous. My hands sweated and my pulse raced. Loads of questions ran through my head: How will the others react? Can I trust them? Am I telling too much? Am I even able to express my most inner feelings in front of practically strangers? I was able to open up, because the situation and the company were just right. (F36)

\section{Discussion}

This study explores what makes learning experiences meaningful and what features enhance meaningful learning in the context of teacher education. In this regard, according to the results, the overall course design, opportunities to gain strong experience and the presence of a broad spectrum of emotions were essential. Favourable conditions for meaningful learning can be created by allowing the combination and mutual influence of personally valued content and shared experiences together with a course structure and methods that support the content and allow appropriate experiences to arise. Thus, the development of teacher education pedagogy and curricula should aim at helping student teachers foster not only pedagogical and critical thinking skills, but also strong emotional skills. It is essential to educate teachers who are able to understand human relationships and develop the potential of the members of the group. This challenge applies not only to the teaching profession, but also to other fields. To answer this challenge, teacher education must yield meaningful learning that prepares student teachers to understand what is to be learned (Daves \& Roberts, 2010). As $\mathrm{Su}(2011$, p. 407) points out, "the new pedagogy must pay attention to the operation of 
agency by focusing on the development of students' feelings, thoughts and actions". In the following section we will discuss the findings of this study and the elements of meaningful learning in teacher education.

\subsection{Course design}

This study showed the importance of course design for student teacher learning. Other studies have noted that creating a suitable learning environment is important for student teachers' professional development (Girvan et al., 2016; Korthagen, 2004). In the participants' written accounts, four features that contributed to their learning experience were emphasised: 1) importance of the phenomenon and theme, 2) common goal and commitment, 3) intensiveness, and 4) linking theory and practice. Interaction and cooperation were identified as important and topical themes for future teachers. They also emphasised the importance of the negotiation of common goals and strategies in groups. The results support previous studies on the significance of student commitment and engagement in meaningful learning. Engagement has been found to contribute to student success (Thomas, 2012) and is part of a recipe for inspiring and quality teaching (Bryson \& Hand, 2007; McCormick, Cappella, Connor, \& McClowry, 2015). Its importance lies in its power to transform students from consumers to co-producers of knowledge (Taylor \& Robinson, 2012) and as a means to achieve active student participation (Zepke, 2013). In this study, this kind of engagement was achieved in a short time through open negotiations with the student group about the values of the group and the nature of the learning process. In particular, intensiveness and linking theory and practice were clearly related to strong student commitment. Although the course was not integrated with practical work in schools, the course structures and social processes enabled the participants to experience the course themes in practice and develop these experiences further in the light of the theories. Earlier research supports our finding that teacher education pedagogy that combines fruitful practical experiences and reflection is necessary for preservice teachers' understanding of the connection between theory and practice (Korthagen, 2010; Harford \& MacRuairc, 2008; Orland-Barak \& Yinon, 2007).

Such findings point towards a new kind of teaching culture in teacher education. Designing courses that support student meaningful learning is considered one of the core features of teacher education, and this necessitates a change in working practices and in the role of the teacher educator. Sterling (2003, p. 289) points out that "there has to be an intent on the part of the designers/teachers born of their own learning, to construct a learning system through 
which they can encourage others to explore epistemic change, as a collaborative inquiry". In creating a collaborative inquiry with students the educator must be sensitive to student emotions and responsiveness, as Bryson and Hand (2007, pp. 357-359) observe: "enthusiastic and engaged teachers are a prerequisite for student engagement”.

Recognising the necessary course design elements that make it possible for students to have meaningful learning experiences can help to create an environment where the other elements of meaningful learning - i.e., strong experience and a broad spectrum of emotions - can be present.

\subsection{Gaining strong experience}

$\mathrm{Su}$ (2011) brings the two forms of student learning to the fore. Students can "learn either because they reactively need to be adaptive to avoid being left behind or because they proactively have a desire to be challenged and improve simply for their own sake" (Su, 2011, p. 405). In the present study, the participants' meaningful learning experiences highlighted this latter aspect of learning by bringing to the fore the aspects of daring and commitment. In addition to these aspects, subjectivity and caring (Nilsson et al., 2015), being heard and accepted within the group, and sharing and equality were also typical aspects of their learning experience. In this regard, the participants' experiences approach the concept of personalised learning that, according to Deakin Crick and Wilson (2005), necessitates a profound sense of the individuals' own worth to others. In the studied course module, the participants felt their contribution was meaningful to the group, which in turn engaged them in learning with high energy and made changes more likely to occur in their values - dimensions that are considered typical of meaningful learning (Dee Fink, 2013; Hakkarainen et al., 2007).

The students also highlighted the central role of the teacher in line with previous literature regarding the role of the teacher in meaningful learning (e.g. Bryson \& Hand, 2007; Hooks, 1994). According to Bryson and Hand (2007), educators must be sensitive to students' sense of equity and justice to be able to develop trust among participants. In this study, the participants considered the example given by the teacher as central in the creation of a trustful atmosphere of sharing. The ability of the teacher to share his or her own experiences and life story was considered a key element in enabling meaningful interaction. Kember, Lee, and $\mathrm{Li} \mathrm{(2001)} \mathrm{also} \mathrm{emphasise} \mathrm{the} \mathrm{importance} \mathrm{of} \mathrm{sense} \mathrm{of} \mathrm{community} \mathrm{in} \mathrm{student} \mathrm{learning.} \mathrm{In}$ their study, however, communities were formed in a natural way over a long period. This 
study, however, shows that a sense of community can be established in a shorter period of time and that the students' sense of community can be encouraged by the course design and the teacher's role and relationship with the group.

\subsection{Broad spectrum of emotions}

In this study, the ability to express and explore a broad spectrum of emotions within the group was experienced as the third essential dimension for meaningful learning. The fact that emotions were emphasised in the participants' accounts challenges teacher education. As Dewey (2004, p. 51) expresses: "Whereas rational consciousness is seen as the core of the actions of human learners, human affect ... tends to be marginalised; feelings or sensations simply are not ways of knowing at all”. For a long time, this split between knowledge and emotions has also been at the core of higher learning, even though the absence of affect has been found to lead to the reification of human thought and action and holding learning to a satisfactory level instead of more through learning processes (Barnett, 2000). Teachers genuinely express, as well as fake and hide, both their positive and negative emotions: faked positive and negative emotions are negatively related to teacher well-being (Taxer \& Frenzel, 2015). According to our results, the student teachers were allowed and even encouraged to experience a variety of emotions that made their learning more personally meaningful. Instead of repressing emotions, they were accepted and considered a natural part of the learning process. In the participants' experience, acceptance of emotions contributed to a sense of engagement and participation in the course (e.g. Su, 2011).

\section{Recommendations}

To enhance meaningful learning, teacher education needs to challenge itself in at least two ways. Firstly, teacher education should challenge itself to go from being the top producer of new educational knowledge and pedagogical practices to the highest arena of exploration of human emotions in teaching and learning. In our research, it was characteristic of the student teachers' meaningful learning experience that a wide range of emotions was both felt and dared to be expressed. Although previous research suggests that teacher behaviour is significantly influenced by emotional aspects and emotions can either hinder or motivate learning (e.g. Dirkx, 2001; Korthagen \& Evelein, 2016), it has become evident that university courses in general suffer a deficit of emotional experience (e.g. Dewey, 2004; Hooks, 1994). Universities emphasise knowledge, whereas emotional aspects, not to mention emotional 
extremes, are even consciously guarded against in the planning of courses. Furthermore, teacher education should specifically acknowledge the caring aspects of teaching, as these have an influence on teachers' well-being and pupils' learning (Nilsson et al., 2015). This study showed that creating space for experiencing both positive and even uncomfortable emotions (e.g. Sterling, 2003) are necessary elements in meaningful learning.

Secondly, teacher education should trial a wider variety of course designs aimed at enabling and facilitating meaningful learning. Our case offers some evidence that a well-planned intensive course design can generate meaningful learning experiences. Teacher educators should challenge themselves to be more daring to choose unknown paths in the learning process and allow more opportunity for the learning group itself to lead the way (see Korthagen, 2010, p. 104). The role of the teacher in student engagement is crucial. Our results are in line with Bryson and Hand's (2007) conclusion that there are three levels of engagement that teaching staff must consider: 1) devoting oneself to discourse with the students, 2) feeling enthusiasm for the subject, and 3) showing professionalism when dealing with teaching and learning processes. Our study also showed that the teacher's ability to negotiate group processes together with students and their sensitivity to the students' affect can help to enable social processes within the group that support the emergence of meaningful learning experiences (e.g. Su, 2011). Furthermore, as Hooks (1994, p. 155) describes, when a teacher brings their own passion to the classroom they are met with other passions, which results in powerful emotional reactions, whereas restrictive teaching denies and hinders emotions.

\subsection{Limitations and recommendations for future studies}

Certain limitations of the research process should be considered. Firstly, the authors of this article were also teachers in the course under study. Although knowing the topic well can be seen in some sense as an advantage, this could also be seen to compromise the reliability and objectivity of the data collection and analysis. In order to minimize this, the data from each small group was not analysed by the responsible teacher but by two other members of the team.

Secondly, to avoid placing additional demands on the students and to get a broad view of the course, the students' course assignments were used as data. The essay theme guided the 
student teachers to theorise and write about a meaningful experience or group phenomenon encountered during the course. It was not determined which experience, positive or negative, the students would choose. However, as the assignment steered the students to write about something that took place during the course, it is possible that some dimensions significant for the students' learning were not included in the essays as they were not present in the course. The variety of experiences present in their essays and the strong emphasis that was given to certain dimensions, however, suggest that the study has, despite this flaw, been able to form a rich picture of the phenomenon. Regarding the ethical dimension, the purpose of the study was explained to the participants and explicit permission to use the essays as data in the study was asked from students.

This study provides insight into what is considered meaningful in student learning in the specific context of a teacher education course module. Further study is needed on meaningful learning experiences and teachers' roles in other types of courses and topics. Specifically, various implementations of courses that are positively evaluated should be investigated further in order to clarify practices and conceptions and to shed new light on the characteristics of meaningful learning. 


\section{References}

ACER (2008). Attracting, engaging and retaining: New conversations about learning. Australasian student engagement report. Camberwell, Victoria: Australian Council for Educational Research.

Allardt, A. C., \& Gallant, A. (2012). Is this a meaningful learning experience? Interactive critical self-inquiry as investigation. Studying Teacher Education, 8(3), 261-273. doi: $10.1080 / 17425964.2012 .719128$

Ausubel, D. P., \& Fitzgerald, D. (1961). Meaningful learning and retention: Intrapersonal cognitive variables. Review of Educational Research, 31(5), 500-510. doi: $10.3102 / 00346543031005500$

Barnett, R. (2000). Supercomplexity and the curriculum. Studies in Higher Education, 25(3), 255-265. doi: 10.1080/713696156

Beijaard, D., Meijer, P., \& Verloop, N. (2004). Reconsidering research on teachers' professional identity. Teaching and Teacher Education, 20(2), 107-128. doi: 10.1016/j.tate.2003.07.001

Berger, P. L., \& Luckman, T. (1967). The social construction of reality. Harmondsworth, UK: Penguin.

Billett, S. (2009). Conceptualizing learning experiences: contributions and mediations of the social, personal, and brute. Mind, Culture, and Activity, 16(1), 32-47. doi: $10.1080 / 10749030802477317$

Braun, V., \& Clarke, V. (2006). Using thematic analysis in psychology. Qualitative Research in Psychology, 3(2), 77-101. doi: 10.1191/1478088706qp063oa

Bredo, E. (1994). Reconstructing educational psychology: Situated cognition and Deweyian pragmatism. Educational Psychologist, 29(1), 23-35. doi: 10.1207/s15326985ep2901_3 
Brookfield, S. D. (1986). Adult learning: A comprehensive analysis of principles and effective practice. Milton Keynes, England: Open University Press.

Bruner, J. (1990). Acts of learning. Cambridge, MA: Harvard University Press.

Bryson, C., \& Hand, L. (2007). The role of engagement in inspiring teaching and learning. Innovations in Education and Teaching International, 44(4), 349-362. doi: $10.1080 / 14703290701602748$

Daves, D. P., \& Roberts, J. G. (2010). Online teacher education programs: social connectedness and the learning experience. Journal of Instructional Pedagogies, 4, 19. Retrieved from https://eric.ed.gov/?id=EJ1096997

Deakin Crick, R., \& Wilson, K. (2005). Being a learner: A virtue for the 21st century. British Journal of Educational Studies, 53(3), 359-374. Doi: 10.1111/j.14678527.2005.00300.x

Dee Fink, L. (2013). Creating significant learning experiences: An integrated approach to designing college courses. San Francisco: John Wiley \& Sons, Inc.

Dewey, J. (2004). Democracy and education. Mineola, New York: Dover Publications, Inc.

Dirkx, J. M. (2001). The power of feelings: Emotion, imagination, and the construction of meaning in adult learning. New Directions for Adult and Continuing Education, 2001(89), 63-72. doi:10.1002/ace.9

Duran, R. L., \& Kelly, L. (1994). The role of social experience in the development of communication competence. Communication Research Reports, 11(2), 119-126. doi: $10.1080 / 08824099409359949$.

Edwards, A., \& D'Arcy, C. (2004). Relational agency and disposition in sociocultural accounts of learning to teach. Educational Review, 56(2), 147-155. doi: $10.1080 / 0031910410001693236$ 
Edwards, A., \& Protheroe L. (2003). Learning to see in classrooms: what are student teachers learning about teaching and learning while learning to teach in schools? British Educational Research Journal, 29(2), 227-242. doi: 10.1080/0141192032000060957

Fiddler, M., \& Marienau, C. (2008). Developing habits of reflection for meaningful learning. New Directions for Adult and Continuing Education, 118, 75-85. doi: 10.1002/ace. 297

Girvan, C., Conneely, C., \& Tangney, B. (2016). Extending experiential learning in teacher professional development. Teaching and Teacher Education, 58, 129-139. doi: 10.1016/j.tate.2016.04.009

Goleman, D. (1995). Emotional Intelligence. New York: Bantam Books.

Hakkarainen, P., Saarelainen, T., \& Ruokamo, H. (2007). Towards meaningful learning through digital video supported, case based teaching. Australasian Journal of Educational Technology, 23(1), 87-109. doi: 10.14742/ajet.1275

Harford, J., \& MacRuairc, G. (2008). Engaging student teachers in meaningful reflective practice. Teaching and Teacher Education, 24(7), 1884-1892. doi:

10.1016/j.tate.2008.02.010

Heidegger, M. (1978). Being and time. Oxford: Blackwell.

Heikkinen, H. L. T., Tynjälä, P., \& Kiviniemi, U. (2011). Integrative pedagogy in practicum: Meeting the second order paradox of teacher education. In M. Mattson, T. V. Eilertsen, \& D. Rorrison (Eds.), A practicum turn in teacher education (pp. 91-112). Rotterdam: Sense Publishers.

Hooks, B. (1994). Teaching to transgress: Education as the practice offreedom. New York: Routledge.

Jarvis, P. (1987). Meaningful and meaningless experience: towards an analysis of learning 
from life. Adult Education Quarterly, 37(3), 164-172. doi:

$10.1177 / 0001848187037003004$

Jonassen, D., Davidson, M., Collins, M., Campbell, B., \& Bannan Haag, B.

(1995).Constructivism and computer-mediated communication in distance education. The American Journal of Distance Education, 9(2), 7-26. doi:

$10.1080 / 08923649509526885$

Jonassen, D. H., \& Strobel, J. (2006). Modeling for meaningful learning. In D. Hung \& M. S. Khine (Eds.), Engaged Learning with Emerging Technologies (pp. 1-27). Dordrecht: Springer.

Keller, M. M., Frenzel, A. C., Goetz, T., Pekrun, R., \& Hensley, L. (2014). Exploring teacher emotions: A literature review and an experience sampling study. In P. W. Richardson, S. Karabenick, \& H. M. G. Watt (Eds.), Teacher Motivation: Theory and Practice (pp. 69-82). New York: Routledge.

Kember, D., Lee, K., \& Li, N. (2001). Cultivating a sense of belonging in part-time students. International Journal of Lifelong Education, 20(4), 326-341. doi: $10.1080 / 02601370117754$

Keskitalo, T., Pyykkö, E., \& Ruokamo, H. (2011). Exploring the meaningful learning of students in second life. Educational Technology \& Society, 14(1), 16-26.

Korthagen, F. A. J. (2001a). Building a realistic teacher education program. In F. A. J. Korthagen (Ed.), Linking practice and theory. The pedagogy of realistic teacher education (pp. 69-87). London: Lawrence Erlbaum Associates.

Korthagen, F. A. J. (2001b). Helping individual student teachers become reflective: The supervisory process. In F. A. J. Korthagen (Ed.), Linking practice and theory. The pedagogy of realistic teacher education (pp. 108-130). London: Lawrence Erlbaum Associates.

Korthagen, F. A. J. (2004). In search of the essence of a good teacher: towards a more holistic 
approach in teacher education. Teaching and Teacher Education, 20(1), 77-97. doi: 10.1016/j.tate.2003.10.002

Korthagen, F. A. J. (2010). Situated learning theory and the pedagogy of teacher education: Towards an integrative view of teacher behavior and teacher learning. Teaching and Teacher Education, 26(1), 98-106. doi: 10.1016/j.tate.2009.05.001

Korthagen, F. A. J., \& Evelein, F. G. (2016). Relations between student teachers' basic needs fulfillment and their teaching behavior. Teaching and Teacher Education, 60, 234244. doi: $10.1016 /$ j.tate. 2016.08 .021

Kubanyiova, M., \& Crookes, G. (2016). Re-envisioning the roles, tasks, and contributions of language teachers in the multilingual era of language education research and practice. The Modern Language Journal, 100(S1), 117-132. doi: 10.1111/modl.12304

Kuh, G., Kinzie, J., Buckley, J., Bridges, B. K., \& Hayek, J. C. (2006). What matters to student success: A review of the literature. Commissioned Report for the National Symposium on Postsecondary Student Success: Spearheading a Dialog on Student Success. Retrieved from http://nces.ed.gov/npec/pdf/kuh_team_report.pdf

Lave, J., \& Wenger, E. (1991). Situated learning: Legitimate peripheral participation. Cambridge, England: Cambridge University Press.

Loughran, J. J. (2002). Effective reflective practice. In search of meaning in learning about teaching. Journal of Teacher Education, 53(1), 33-43. doi: $10.1177 / 0022487102053001004$

Marton, F. (1994). Phenomenography. In T. Husén \& T. N. Postlethwaite (Eds.), The international encyclopedia of education (2nd ed.). Vol 8 (pp. 4424-4429). Oxford: Pergamon.

McCormick, M. P., Cappella, E., O’Connor, E. E., \& McClowry, S. G. (2015). Social- 
Emotional Learning and Academic Achievement Using Causal Methods to Explore Classroom-Level Mechanisms. AERA Open, 1(3), 1-26. doi:

$10.1177 / 2332858415603959$

Merriam, S. B., \& Clark, M. C. (1993). Learning from life experience: What makes it significant? International Journal of Lifelong Education, 12(2), 129-138. doi: $10.1080 / 0260137930120205$

Miles, M. B., \& Huberman, A. M. (1994). Qualitative data analysis. Thousand Oaks: Sage.

Moate, J., \& Ruohotie-Lyhty, M. (2014). Identity, agency and community: reconsidering the pedagogic responsibilities of teacher education. British Journal of Educational Studies, 62(3), 249-264. doi: 10.1080/00071005.2014.955456

Munthe, E., \& Rogne, M. (2015). Research based teacher education. Teaching and Teacher Education, 46, 17-24. doi: 10.1016/j.tate.2014.10.006

Nilsson, M., Ejlertsson, G., Andersson, I., \& Blomqvist, K. (2015). Caring as a salutogenic aspect in teachers' lives. Teaching and Teacher Education, 46, 51-61. doi: 10.1016/j.tate.2014.10.009

Novak, J. D. (2002). Meaningful learning: The essential factor for conceptual change in limited or inappropriate propositional hierarchies leading to empowerment of learners. Science Education, 86(4), 548-571. doi: 10.1002/sce.10032

Okukawa, H. (2008). If your learning experience is meaningful for you, how have you been constructing that meaning? A study of adult learners in Bangkok. International Forum of Teaching and Studies, 4(1), 46-61.

Orland-Barak, L., \& Yinon, H. (2007). When theory meets practice: What student teachers learn from guided reflection on their own classroom discourse. Teaching and Teacher Education, 23(6), 957-969. doi: 10.1016/j.tate.2006.06.005

Packer, M. J., \& Goicoechea, J. (2000). Sociocultural and constructivist theories of learning: 
Ontology, not just epistemology. Educational Psychologist, 35(4), 227-241. doi: 10.1207/S15326985EP3504_0

Parkes, R. J. (2013). Challenges for curriculum leadership in contemporary teacher education. Australian Journal of Teacher Education, 38(7), 112-128. doi: 10.14221/ajte.2013v38n7.8

Pena-Shaff, J. B., \& Nicholls, C. (2004). Analyzing student interactions and meaning construction in computer bulletin board discussions. Computers \& Education, 42(3), 243-265. doi: 10.1016/j.compedu.2003.08.003

Rasku-Puttonen, H., Klemola, U., \& Kostiainen, E. (2011). Supporting student teachers' social interaction competence in teacher education. In M. Kontoniemi \& O.-P. Salo (Eds.), Educating teachers in the PISA paradise. Perspectives on teacher education at a Finnish university (pp. 89-102). University of Jyväskylä. Jyväskylä Teacher Training School. Publications 12.

Rodgers, C. R., \& Raider-Roth, M. B. (2006). Presence in teaching. Teachers and Teaching: theory and practice, 12(3), 265-287. doi: 10.1080/13450600500467548

Schelfhout, W., Dochy, F., Janssens, S., Struyven, K., Gielen, S., \& Sierens, S. (2006). Educating for learning-focused teaching in teacher education: The need to link learning content with practice experiences within an inductive approach. Teaching and Teacher Education, 22(7), 874-897. doi: 10.1016/j.tate.2006.04.003

Schmidt, M. (2010). Learning from teaching experience: Dewey's theory and preservice teachers' learning. Journal of Research in Music Education, 58(2), 131-146. doi: $10.1177 / 0022429410368723$

Sharan, Y. (2015). Meaningful learning in the cooperative classroom. Education 3-13, 43(1), 83-94. doi: 10.1080/03004279.2015.961723

Sousa, A. T. O., Formiga, N. S., Oliveira, S. H. S., Costa, M. M. L., \& Soares, M. J. G. O. 
(2015). Using the theory of meaningful learning in nursing education. Revista Brasileira Enfermagem, 68(4), 626-635. doi: 10.1590/0034-7167.2015680420i

Stein, S.J., Isaacs, G., \& Andrews, T. (2004). Incorporating authentic learning experiences within a university course. Studies in Higher Education, 29(2), 239-258. doi: $10.1080 / 0307507042000190813$

Sterling, S. (2003). Whole systems thinking as a basis for paradigm change in education: Explorations in the context of sustainability. Bath: University of Bath.

Su, Y.-H. (2011). The constitution of agency in developing lifelong learning ability: the 'being' mode. Higher Education, 62(4), 399-412. doi: 10.1007/s10734-010-9395-6

Taniguchi, S. T., Freeman, P. A., \& LeGrand Richards, A. (2005). Attributes of meaningful learning experiences in an outdoor education program. Journal of Adventure Education and Outdoor Learning, 5(2), 131-144. doi: $10.1080 / 14729670585200661$

Taxer, J. L., \& Frenzel, A. C. (2015). Facets of teachers' emotional lives: A quantitative investigation of teachers' genuine, faked, and hidden emotions. Teaching and Teacher Education, 49, 78-88. doi: 10.1016/j.tate.2015.03.003

Taylor, C., \& Robinson, C. (2012). Student engagement in higher education: theory, context, practice, Journal of Applied Research in Higher Education, 4(2), 94-108. doi: 10.1108/jarhe.2012.53304baa.001

Thomas, L. (2012). Building student engagement and belonging in Higher Education at a time of change. Paul Hamlyn Foundation, 100. Retrieved from http://www.phf.org.uk/wp-content/uploads/2014/10/What-Works-report-final.pdf

Tsai, C.-W., Shen, P.-D., \& Chiang, Y.-C. (2013). Research trends in meaningful learning research on e-learning and online education environments: A review of studies published in SSCI-indexed journals from 2003 to 2012. British Journal of Educational Technology, 44(6), E179-E184. doi: 10.1111/bjet.12035 
Tynjälä, P., Virtanen, A., Klemola, U., Kostiainen, E., \& Rasku-Puttonen, H. (2016).

Developing social competence and other generic skills in teacher education: applying the model of integrative pedagogy. European Journal of Teacher Education, 39(3), 368-387. doi: 10.1080/02619768.2016.1171314

Uhrmacher, P. B. (2002). An education of meaning. Curriculum and Teaching Dialogue, $4(1), 67-73$.

University of Jyväskylä Teacher Education Curriculum 2014-2017. Retrieved from https://www.jyu.fi/edupsy/fi/laitokset/okl/en/curriculum/curriculum2014/view

Valli, R., Valli, P., \& Lähdesmäki, S. (2017). Meaningful learning experiences in the Finnish teacher education. Asian Journal of Education and e-Learning, 5(2), 27-35. doi:10.24203/ajeel.v5i2.4471

Virtanen, A., \& Tynjälä, P. (2013). Kohti työelämätaitoja kehittävää yliopistopedagogiikkaa - opiskelijoiden näkökulma [Developing pedagogy for learning of generic skills: university students' point of view]. Yliopistopedagogiikka, 20(2), 2-10.

Watkins, K. E., \& Marsick, V. J. (1992). Towards a theory of informal and incidental learning in organizations. International Journal of Lifelong Education, 11(4), 287300. doi: $10.1080 / 0260137920110403$

Wolfe, P. (2006). The role of meaning and emotion in learning. New Directions for Adult and Continuing Education, 2006(110), 35-41. doi: 10.1002/ace.217

Zeichner, K. (2014). The struggle for the soul of teaching and teacher education in the USA. Journal of Education for Teaching, 40(5), 551-568. doi: $10.1080 / 02607476.2014 .956544$

Zepke, N. (2013). Lifelong education for subjective well-being: how do engagement and active citizenship contribute? International Journal of Lifelong Education, 32(5), 639-651. doi: 10.1080/02601370.2012.753125 
Zepke, N., \& Leach, L. (2002). Contextualised meaning making: One way of rethinking experiential learning and self-directed learning? Studies in Continuing Education, 24(2), 205-217. doi: 10.1080/0158037022000020992

Zepke, N., \& Leach, L. (2010). Improving student engagement: Ten proposals for action. Active Learning in Higher Education, 11(3), 167-177. doi: $10.1177 / 1469787410379680$ 